\title{
Associations between prenatal exposure to cadmium and lead with neural tube defect risks are modified by single-nucleotide polymorphisms of fetal MTHFR and SOD2: a case-control study
}

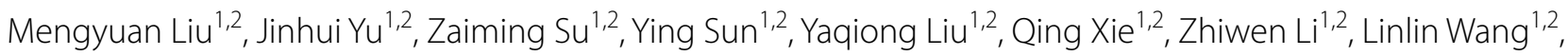
Jie Zhang ${ }^{1,2}$, Lei $\operatorname{Jin}^{1,2^{*}}$ and Aiguo Ren ${ }^{1,2,3^{*}}$ (D)

\begin{abstract}
Background: Prenatal exposure to heavy metals is implicated in the etiology of birth defects. We investigated whether concentrations of cadmium (Cd) and lead $(\mathrm{Pb})$ in umbilical cord tissue are associated with risk for neural tube defects (NTDs) and whether selected genetic variants of the fetus modify their associations.

Methods: This study included 166 cases of NTD fetuses/newborns and 166 newborns without congenital malformations. Umbilical cord tissue was collected at birth or elective pregnancy termination. $\mathrm{Cd}$ and $\mathrm{Pb}$ concentrations were assessed by inductively coupled plasma-mass spectrometry, and 20 single-nucleotide polymorphisms (SNPs) in 9 genes were genotyped. Odds ratios (ORs) with 95\% confidence intervals (Cls) were used to estimate the risk for NTDs in association with metal concentrations or genotype using logistic regression. Multiplicative-scale interactions between the metals and genotypes on NTD risk were assessed with logistic regression, and additive-scale interactions were estimated with a non-linear mixed effects model.

Results: Higher concentrations of Cd were observed in the NTD group than in the control group, but no difference was found for $\mathrm{Pb}$. Concentrations of $\mathrm{Cd}$ above the median level showed a risk effect, while the association between $\mathrm{Pb}$ and NTD risk was not significant in univariate analyses. The association of $\mathrm{Cd}$ was attenuated after adjusting for periconceptional folic acid supplementation. Fetuses with the AG and GG genotypes of rs 4880 in SOD2 (superoxide dismutase 2) tended to have a lower risk, but fetuses with the CT and TT genotypes of rs 1801133 in MTHFR (5,10-methylenetetrahydrofolatereductase) have a higher risk for NTDs when compared to their respective wild-type. rs4880 and Cd exhibited a multiplicative-scale interaction on NTD risk: the association between higher $\mathrm{Cd}$ and the risk for NTDs was increased by over fourfold in fetuses carrying the G allele [OR 4.43 (1.30-15.07)] compared to fetuses with the wild-type genotype. rs 1801133 and Cd exposure showed an additive interaction, with a significant relative excess risk of interaction [RERI $0.64(0.02-1.25)]$.
\end{abstract}

\footnotetext{
*Correspondence: jinlei@bjmu.edu.cn; renag@bjmu.edu.cn

${ }^{1}$ Institute of Reproductive and Child Health/Key Laboratory

of Reproductive Health, National Health Commission of the People's

Republic of China, Peking University, Beijing, China

Full list of author information is available at the end of the article
}

(c) The Author(s) 2021, corrected publication, July 2021. Open Access This article is licensed under a Creative Commons Attribution 4.0 International License, which permits use, sharing, adaptation, distribution and reproduction in any medium or format, as long as you give appropriate credit to the original author(s) and the source, provide a link to the Creative Commons licence, and indicate if changes were made. The images or other third party material in this article are included in the article's Creative Commons licence, unless indicated otherwise in a credit line to the material. If material is not included in the article's Creative Commons licence and your intended use is not permitted by statutory regulation or exceeds the permitted use, you will need to obtain permission directly from the copyright holder. To view a copy of this licence, visit http://creativecommons.org/licenses/by/4.0/. The Creative Commons Public Domain Dedication waiver (http://creativecommons.org/publicdomain/zero/1.0/) applies to the data made available in this article, unless otherwise stated in a credit line to the data. 
Conclusions: Prenatal exposure to $\mathrm{Cd}$ may be a risk factor for NTDs, and the risk effect may be enhanced in fetuses who carry the G allele of rs4880 in SOD2 and T allele of rs 1801133 in MTHFR.

Keywords: Cadmium, Lead, Neural tube defects, Single-nucleotide polymorphisms, Superoxide dismutase 2 (SOD2), 5,10-methylenetetrahydrofolatereductase (MTHFR)

\section{Background}

Neural tube defects (NTDs) are among the most common severe birth defects that include a spectrum of structural malformations caused by failed neural tube closure during early fetal development. The prevalence of this disease remains high in some parts of the world, ranging from 1.3 to 28 in 2000 established pregnancies [1-3]. NTDs are major public health issues due to their high mortality and detrimental impacts on the entire lives of the affected children and their families. Maternal folate deficiency is associated with elevated risk for fetal NTDs [4], and supplementation with folic acid during the periconceptional period can effectively reduce the first occurrence and re-occurrence of the defects [5-8]. However, the mechanisms underlying the association between folate and NTDs remain elusive.

In addition to folate deficiency, other environmental factors may also play a role in NTDs. In populations in which folic acid fortification is implemented, known risk factors, including lack of folic acid supplementation, account for less than half of NTD cases, indicating the need for continued research to identify genetic and environmental factors [9]. Among the variety of environmental factors, heavy metal exposure has attracted much attention. Animal studies have shown that intraperitoneal injection of $\mathrm{CdCl} 2$ on gestational day (GD) 8 could induce NTDs in fetal mice [10]. Cadmium $(\mathrm{Cd})$ and lead $(\mathrm{Pb})$ have also exhibited a negative impact on neural tube development in chicks $[11,12]$ and zebrafish [13]. A few epidemiological studies have investigated the associations between prenatal exposure to $\mathrm{Cd}$ or $\mathrm{Pb}$ and birth defects. A study conducted in England revealed that a higher concentration of $\mathrm{Pb}$ (defined as $\geq 10 \mu \mathrm{g} / \mathrm{L}$ ) in domestic drinking water was associated with a greater risk for NTDs [14]. NTD cases had higher levels of $\mathrm{Cd}$ and $\mathrm{Pb}$ in fetal or maternal serum $[15,16]$ and in amniotic fluid [17] than controls. In addition, maternal blood $\mathrm{Cd}$ and $\mathrm{Pb}$ levels were found to be linked to other adverse birth outcomes, such as lower birthweight [18-20]. However, in these studies, prenatal exposure to heavy metals was predominantly assessed in maternal serum or in the external environment, which could only be regarded as a surrogate of fetal exposure, and only a few studies used direct exposure markers from the fetus, which used metal concentrations in umbilical cord blood [16, 19]. In this study, we used umbilical cord tissue to measure metal exposure of the fetus because this tissue has the same origin as the fetus and can exclude potential variations that might be introduced by different placental functions.

In addition, genetics may modify the effect of environmental factors on human health. The toxicity of $\mathrm{Cd}$ and $\mathrm{Pb}$ is largely due to their ability to destruct the antioxidant system and induce an excessive accumulation of reactive oxygen species (ROS) in tissue and cellular components $[21,22]$. Thus, genes involved in the antioxidant pathway may influence the association between heavy metal exposure and NTD occurrence. Selenoproteins, which possess a selenocysteine center, play critical roles in eliminating ROS caused by heavy metals through their antioxidant capabilities [23]. The expression of selenocysteine is regulated by cis-acting elements (i.e., selenocysteine insertion sequence, SECIS) and trans-acting factors, including SECIS binding protein 2 (SBP2), eukaryotic elongation factor selenocysteine-tRNA specific (eEFSec), and ribosomal protein L30 (RPL30). Meanwhile, selenoprotein releases selenium into the central nervous system through apolipoprotein E receptor 2 (ApoER2, encoded by gene LRP8) on the blood-brain barrier, and the transportation of selenoprotein in the nervous system also depends on ApoER2 [24]. Another important mechanism to protect the body from ROS is the superoxide dismutase (SOD) enzymes. SODs catalyze the transformation of superoxide anion $(\mathrm{O} 2 \cdot-)$ into $\mathrm{H}_{2} \mathrm{O}_{2}$ and oxygen; otherwise, superoxide anion would give rise to the generation of ROS [25]. In addition, 5,10-methylenetetrahydrofolatereductase (MTHFR) and methyltetrahydrofolatehomocysteine methyltransferase reductase (MTRR) are crucial enzymes involved in folate one-carbon metabolism, which plays an essential role in neural tube closure through mechanisms yet to be elucidated.

In this study, we investigated the associations between prenatal exposure to $\mathrm{Cd}$ and $\mathrm{Pb}$, using their concentrations in umbilical cord tissue, and the risk for NTDs, and examined possible interactions between $\mathrm{Cd}$ and $\mathrm{Pb}$ exposure and 20 SNPs in 9 genes involved in detoxification and folate metabolism pathways on the occurrence of NTDs. 


\section{Materials and methods Study subjects}

This case-control study was conducted with subjects recruited from Shanxi Province of northern China [26]. This province is characterized by heavy coal mining and coal-consuming industries, mountainous and arid land, and a high prevalence rate of NTDs, 31.5/10,000 in 2014 [27]. The subjects included fetuses from elective termination of pregnancy as well as newborn infants. NTD cases were diagnosed by fetal ultrasound scan or physical examination at birth or pregnancy termination. 1:1 matched healthy newborns were recruited from the same hospital according to maternal residence (same county) and the date of last menstruation $( \pm 4$ weeks with the case mother). Overall, this study included 166 NTD cases (51 with anencephaly, 98 with spina bifida, and 17 with encephalocele), and 166 non-malformed controls recruited during 2004 and 2016. All the subjects included in this study were Han Chinese. This study was approved by the biomedical ethics committee of Peking University (Beijing, China), and all mothers provided consent before participation.

\section{Questionnaire interview}

A structured questionnaire was administered by local health-care professionals through face-to-face interviews with the mothers before discharge from the birthing hospitals. The questionnaire included sociodemographic information, date of last menstruation, disease history, history of pregnancy affected by birth defects, periconceptional folate fortification, and factors related to environmental exposure of toxicity and dietary habits.

\section{Laboratory assessment of $\mathrm{Cd}$ and $\mathrm{Pb}$ concentrations}

Umbilical cord tissues on the fetal end were collected immediately after normal delivery or pregnancy termination and subsequently stored at $-20{ }^{\circ} \mathrm{C}$ in a polyethylene bag. When element assessment was performed, approximately $2 \mathrm{~g}$ of umbilical cord tissue samples were taken. First, the samples were thawed at $4{ }^{\circ} \mathrm{C}$, rinsed 3 times with deionized water, and blotted on absorbent paper to remove excess water. Next, the tissues were cut into pieces for assessment. Each sample was weighed and put into a glass jar, which was subsequently covered by ventilated aluminum foil and freeze-dried in a CHRIST freeze dryer (ALPHA 2-4 LSC, Martin Christ Gefriertrocknungsanlagen $\mathrm{GmbH}$, Osterode am Harz, Germany). The jar was set on the rack of the solidifying dryer, which was next put in a refrigerator at $-70{ }^{\circ} \mathrm{C}$ for at least $4 \mathrm{~h}$. The vacuum pump was preheated for $30 \mathrm{~min}$, and then the rack was moved into the drying chamber.

For each assessment, $0.2 \mathrm{~g}$ of dried umbilical cord specimen was accurately weighed and digested in a solution of $3 \mathrm{~mL}$ of nitric acid (BV-grade III) and $0.5 \mathrm{~mL}$ of hydrogen peroxide in a high-pressure microwave acid digestion system (Ultra WAVE, Milestone, Italy) with quart vessels for $1 \mathrm{~h}$. After digestion, $1 \mathrm{~mL}$ of the sample was moved to a $2.0 \mathrm{~mL}$ Eppendorf tube, and $0.1 \mathrm{~mL}$ of the internal standard agent (rhodium concentration as $20 \mathrm{ng} /$ $\mathrm{mL})$, and super-pure deionized water $(18.2 \mathrm{M} \Omega . \mathrm{cm})$ was added to reach a final volume of $2 \mathrm{~mL}$. This solution was finally used to determine $\mathrm{Cd}$ and $\mathrm{Pb}$ concentrations with inductively coupled plasma mass spectrometry (ICP-MS) [28] (Agilent Technologies, 7700x, Hachioji, Japan).

The standard curves were calibrated and validated by certified standards of Chinese national reference material (GSB 04-1714 - 2004). As mentioned above, the ICPMS system was calibrated using rhodium as the internal reference. To eliminate the effects of possible contamination during the process of digestion and sample preparation, a blank solution was prepared and carried through every 20 samples analyzed. The correlation coefficients of all calibration lines were $>0.999$. The reference sample, which was made of pig liver (GBW10051), was carried through each lot of samples analyzed to test the stability of the process. The limits of detection (LOD) for $\mathrm{Cd}$ and $\mathrm{Pb}$ were $0.006 \mathrm{ng} / \mathrm{mL}$ and $0.0172 \mathrm{ng} / \mathrm{ml}$, respectively. The detection rate for $\mathrm{Cd}$ and $\mathrm{Pb}$ were 98.2 and $100 \%$, respectively.

\section{SNP selection}

As discussed in the background, we focused on genes that are involved in detoxification and folate metabolism pathways. The SNPs included in this study were either those that have been reported in the literature or the tagSNPs of the analyzed gene, which were obtained by Haploview4.2 software. In total, 20 SNPs were selected (Supplementary Table 1): SEPP1 (rs7579, rs230820); SBP2 (rs74458996, rs76367332, rs3211707, rs80298072); SEP15 (rs5859); eEFSec (rs10934853, rs2977565, rs77776385, rs1702118, rs2981017); RPL30 (rs150471706, rs4735522); LRP8 (rs3737983, rs2297660); SOD2 (rs4880, rs5746105); MTRR (rs3776467); MTHFR (rs1801133). The call rates for genotyping of all SNPs were higher than $98.8 \%$

\section{DNA extraction and SNP genotyping}

Genomic DNA was extracted from umbilical cord tissue according to the manufacturer's instruction (blood or tissue genomic DNA extraction kit, TIANGEN, Beijing). The DNA purity was measured by the Nanodrop microspectrophotometer (Thermo Fisher Scientific. Inc), and the A260/A280 ratio was controlled within 1.8-2.0. The DNA sample was then stored in at $-20{ }^{\circ} \mathrm{C}$ until genotyping.

The DNA template containing the SNPs locus region was amplified by PCR technology, and then the PCR 
product was subjected to a single base extension reaction using specific extension primers. High-throughput genotyping of single nucleotide polymorphisms (SNPs) was performed using Matrix-Assisted Laser Desorption Ionization Time of Flight Mass Spectrometry (MALDITOF-MS) in a gene mass spectrometry system (Sequenom, San Diego, CA, USA).

\section{Statistical analysis}

The distribution of $\mathrm{Cd}$ and $\mathrm{Pb}$ concentrations was illustrated as median together with interquartile interval (P25-P75). The concentrations of $\mathrm{Cd}$ and $\mathrm{Pb}$ were compared between the NTD cases and controls through nonparametric analysis. $\mathrm{Cd}$ and $\mathrm{Pb}$ concentrations were dichotomized into two levels by the median of all subjects. Associations between $\mathrm{Cd}$ and $\mathrm{Pb}$ exposure and risks for NTDs were evaluated by odds ratio (OR) through logistic regression, and the precision of the estimation was indicated by its $95 \%$ confidence interval (95\% CI). Periconceptional folate supplementation was included in the model as a confounder in multivariable logistic regression analysis. Since dichotomized variables are easily understandable and interpretable, especially in analyzing two-factor interactions, we categorized $\mathrm{Cd}$ and $\mathrm{Pb}$ concentrations by their median concentrations.

Hardy-Weinberg Equilibrium (HWE) was tested for each SNP, and if the genotype distribution did not conform with HWE, the SNP would not be included in subsequent analysis. The associations between SNPs and the risk for NTDs were evaluated by unconditional logistic regression with or without the adjustment of folic acid supplementation. Next, we stratified our logistic regression model according to genotypes and produced a cross-product term (multiplicative scale) to evaluate the potential modifying effect of a specific genotype on the association between $\mathrm{Cd}$ or Pb levels and NTD risk. Meanwhile, we calculated additive scale interaction using the non-linear mixed effects model described by Demidenko [29]. Statistical analyses were performed with SPSS Version 26.0. A two-sided $P$ value of $<0.05$ was considered statistically significant.

We chose dichotomized model to analyze the data of this study, although continuous variables may be better powered. However, if the relationship to be examined is nonlinear, the use of continuous variables may miss the opportunity to find such a relationship. In addition, dichotomized variables are directly understandable and interpretable, especially for two-factor interaction analyses.

\section{Results}

Maternal demographic and obstetric characteristics of NTD cases and controls are illustrated in Table 1. The case group had a shorter gestation and a higher pre-pregnancy body mass index (BMI), were more likely to report a history of pregnancy affected by birth defects and fever or flu in the first trimester but less likely to take a folic acid supplement. No differences in maternal age, parity,

Table 1 Maternal characteristics of neural tube defect cases and controls

\begin{tabular}{|c|c|c|c|}
\hline Characteristic & $\begin{array}{l}\text { Cases }(n=166)^{\text {a }} \\
\text { No. }(\%)\end{array}$ & $\begin{array}{l}\text { Control }(n=166)^{\text {a }} \\
\text { No. }(\%)\end{array}$ & $P^{\mathrm{b}}$ \\
\hline Maternal age (years) & & & 0.259 \\
\hline$<25$ & $57(35.2)$ & $63(38.4)$ & \\
\hline $25-29$ & $46(28.4)$ & $55(33.5)$ & \\
\hline$\geq 30$ & $59(36.4)$ & $46(28.0)$ & \\
\hline High school or above education & $27(16.6)$ & $54(32.5)$ & 0.001 \\
\hline Maternal farming occupation & $129(77.7)$ & $126(75.9)$ & 0.795 \\
\hline Pre-pregnancy body mass index $\geq 24$ & $86(53.4)$ & $61(37.7)$ & 0.005 \\
\hline Maternal smoking or second-hand smoking & $134(85.4)$ & $131(80.4)$ & 0.300 \\
\hline Maternal folic acid use & $66(40.5)$ & $81(52.9)$ & 0.032 \\
\hline Parity & & & 0.424 \\
\hline Primiparae & $89(56.0)$ & $84(51.5)$ & \\
\hline Multiparae & $70(44.0)$ & $79(48.5)$ & \\
\hline Gestational weeks at sample collection & & & $<0.001$ \\
\hline$<37$ & 138(83.1) & $6(3.6)$ & \\
\hline$\geq 37$ & 28(16.9) & 160(96.4) & \\
\hline History of pregnancy affected by birth defects & $9(5.5)$ & $1(0.6)$ & 0.020 \\
\hline Maternal fever or flu in 1st trimester & $59(36.6)$ & $25(15.3)$ & $<0.001$ \\
\hline
\end{tabular}

${ }^{a}$ The sum of the numbers may not equal the total number due to missing or unknown data

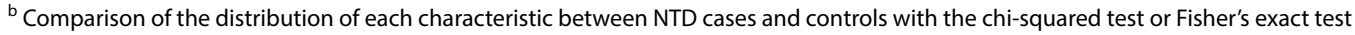


maternal occupation, and smoking or passive smoking were observed between the two groups.

Medians with interquartile intervals of $\mathrm{Cd}$ and $\mathrm{Pb}$ concentrations in the two groups are presented in Table 2. The median concentration of $\mathrm{Cd}$ was significantly higher in cases $(1.30 \mathrm{ng} / \mathrm{g})$ than in controls $(0.93 \mathrm{ng} / \mathrm{g})$ by nonparametric test. No significant difference in $\mathrm{Pb}$ concentrations was observed between the two groups.

Table 3 presents the associations between levels of $\mathrm{Cd}$ and $\mathrm{Pb}$ and the risk for NTDs. The association between $\mathrm{Cd}$ levels and NTD risks was statistically significant in univariate logistic regressions [OR, 1.55 (1.00-2.38), $P=0.049$ ], whereas the $\mathrm{Pb}$ concentrations were not evident [OR, 1.27 (0.83-1.96), $P=0.273]$. Since folic acid supplementation was associated with lower concentrations of $\mathrm{Cd}$ and $\mathrm{Pb}$ in umbilical cord tissue (Supplementary Table 2), folic acid supplementation was adjusted for in multivariable logistic regression. The adjustment for folic acid supplementation attenuated the association between Cd and NTD.

Associations between genotypes of the 20 SNPs in 9 genes and NTD risk were examined. All the SNPs conformed with HWE except rs5746105 in SOD2, which was excluded from subsequent analyses. NTD risk decreased with the number of $\mathrm{G}$ allele in SOD2 rs4880 genotype $(P=0.045)$, while the heterozygous genotype (AG) and homozygous genotype (GG) showed insignificant associations compared with the wild-type [OR, $0.69(0.40-$ 1.20) for AG, OR, 0.17 (0.02-1.45) for GG] (Table 4). In addition, we observed an increasing trend in NTD risk with the number of T alleles in rs1801133 of MTHFR [OR, $1.33(0.67-2.65)$ for CT, OR, $1.92(0.93-3.98)$ for TT]. Associations between other SNPs and NTD risk are presented in Supplementary Table S3.

We next examined the interactions between the two SNPs presented in Table 4 and metal levels on NTD risk (Table 5). Rs4880 G allele carriers in SOD2 (AG and GG genotypes) who had high $\mathrm{Cd}$ exposure exhibited a much stronger association with NTD risk, over fivefold higher, compared to fetuses who had the same genotype but had low Cd exposure [OR, 5.48 (1.90-15.82), $P=0.002$ ]. No such modification effect for the AA genotype was present. Multiplicative-scale interaction between this SNP and $\mathrm{Cd}$ exposure was statistically significant, with an OR of 4.83 (1.48-15.76). The interactive effects were still significant after adjustment for periconceptional folic acid supplementation.

For MTHFR rs1801133, T allele carriers (CT and TT genotypes) with a higher $\mathrm{Cd}$ exposure level showed an increased risk for NTDs [OR, 1.87 (1.14-3.08)], while no such modification effect was found for fetuses with the wildtype (CC). This association was attenuated when folic acid supplementation was adjusted for. No multiplicative-scale interaction between this SNP and Cd exposure on NTD risk was observed, but an additive-scale interaction was found with a relative excess risk of interaction of $0.64(0.02-1.25)$ after adjustment for folic acid supplementation.

\section{Discussion}

In this case-control study, we investigated the associations between concentrations of $\mathrm{Cd}$ and $\mathrm{Pb}$ in umbilical cord tissue and 20 SNPs in 9 genes in metal or folate metabolic pathways with NTD risk, as well as the interactions between metals and SNPs. A suggestive association between Cd levels and NTD risk was observed, whereas the association between Pb level and NTD risk was not evident. More importantly, the SNP rs4880 in SOD2 (AG \& GG vs. AA) and higher Cd exposure showed a multiplicative-scale interaction on NTD risk, and the SNP rs1801133 in MTHFR (CT and TT vs. CC) and higher Cd exposure exhibited an additive-scale interaction on NTD risk, supporting an environmental-genetic interaction in the etiology of NTDs.

Data on $\mathrm{Cd}$ and $\mathrm{Pb}$ concentrations in umbilical cord tissue are scarce. In a Japanese study [30], which used the same methods of metal assessment as our present study, the median values and interquartile ranges of concentrations of $\mathrm{Cd}$ and $\mathrm{Pb}$ in umbilical cord from healthy newborn were $1.16(0.87-1.68) \mathrm{ng} / \mathrm{g}$ for $\mathrm{Cd}$, and 39.9 (33.8-50.1) ng/g for $\mathrm{Pb}$. The Cd level was similar to that of the control group of our present study $[\mathrm{Cd}$, $0.93(0.44-2.68) \mathrm{ng} / \mathrm{g}]$, while the $\mathrm{Pb}$ level is higher than our result [ $\mathrm{Pb}, 24.62(17.17-46.86) \mathrm{ng} / \mathrm{g}]$. On the other hand, several studies have determined concentrations of these two metals in umbilical cord blood [19, 31, 32]. In a Turkish study, the levels of $\mathrm{Cd}$ and $\mathrm{Pb}$ were both significantly higher in NTD cases than in control subjects, as detected either in maternal or infant plasma [16]. So

Table 2 Median (P25-P75) concentration of cadmium (Cd) and lead (Pb) assessed in cord tissue (dry weight) in neural tube defect cases and controls

\begin{tabular}{lllllr}
\hline Metal & All subjects & Cases & Controls & $\boldsymbol{P}^{\text {a }}$ & Maximum-minimum \\
\hline $\mathrm{Cd}(\mathrm{ng} / \mathrm{g})$ & $1.10(0.48-3.09)$ & $1.30(0.57-3.49)$ & $0.93(0.44-2.68)$ & 0.026 & $23.411-0.034$ \\
$\mathrm{~Pb}(\mathrm{ng} / \mathrm{g})$ & $26.18(17.97-48.58)$ & $27.32(18.37-50.34)$ & $24.62(17.17-46.86)$ & 0.211 & $225.572-4.330$ \\
\hline
\end{tabular}

Abbreviations: $P 25$ 25th percentile, $P 75$ 75th percentile

${ }^{\text {a }}$ Comparison of median values between two groups conducted using the Mann-Whitney $\mathrm{U}$ test 
Table 3 Logistic regression analysis of cadmium $(\mathrm{Cd})$ and lead $(\mathrm{Pb})$ concentrations and the risk for neural tube defects

\begin{tabular}{|c|c|c|c|c|c|c|}
\hline Metal level $^{\mathrm{a}}$ & Controls [n (\%)] & Cases [n (\%)] & COR $(95 \% \mathrm{Cl})$ & $P$ & aOR $(95 \% \mathrm{Cl})$ & $P^{b}$ \\
\hline \multicolumn{7}{|l|}{$\mathrm{Cd}$} \\
\hline Low (<26.18 ng/g) & $92(55.4)$ & $74(44.6)$ & 1 & & 1 & \\
\hline High ( $\geq 26.18 \mathrm{ng} / \mathrm{g})$ & $74(44.6)$ & $92(55.4)$ & $1.55(1.00-2.38)$ & 0.049 & $1.44(0.91-2.28)$ & 0.116 \\
\hline \multicolumn{7}{|l|}{$\mathrm{Pb}$} \\
\hline Low (<1.10 ng/g) & $88(53.0)$ & $78(47.0)$ & 1 & & 1 & \\
\hline High ( $\geq 1.10 \mathrm{ng} / \mathrm{g}$ ) & $78(47.0)$ & $88(53.0)$ & $1.27(0.83-1.96)$ & 0.273 & $1.23(0.78-1.94)$ & 0.378 \\
\hline
\end{tabular}

far, we did not find any previous research that explored the relationship between $\mathrm{Cd}$ or $\mathrm{Pb}$ in cord tissue and the risk for NTDs.

We found that maternal fever in the 1st trimester was associated with NTD risk. Hyperthermia during pregnancy has been reported to have a teratogenic effect [33], particularly on the central nervous system [34,35]. Moreover, the teratogenicity of hyperthermia is closely related to the timing of embryogenesis. Fever in the 1st trimester has been associated with brain damage and NTDs [35], while fever during the 2nd trimester has been linked to autism [36] and abnormalities of psychological development [37]. Animal studies further validated the relationship between hyperthermia in early pregnancy and NTDs [38].

Rs4880 is the most extensively studied SNP in SOD2 (MnSOD). This variant causes the alteration of valine amino acid (GTT) to alanine (GCT) at codon 16 (Ala$16 \mathrm{Val})$, which leads to a structural mutation in the mitochondrial targeting sequence (MTS) [39]. MTS is critical for MnSOD to be recognized and enter the mitochondria to become active and exert its function. The AlaMnSOD variant exhibits a higher transport efficiency into the mitochondria than Val-MnSOD, which might be due to the transition from an alpha-helix structure (AlaMnSOD) to a beta-sheet structure (Val-MnSOD) [40]. It has been verified in vitro that MnSOD activity is higher in Ala variants than Val variants [40, 41]. Associations between this variant and a variety of diseases have been extensively investigated; however, there is still no consistent result for definitive assignment of which variant is the culprit for disease occurrence [42]. According to the Genome Aggregation Database (gnomAD, http://gnomad-sg.org/), the percentages of the G allele (Ala variant) in most ethnicities are around 50\%, whereas, in East Asia, the frequency is at 0.149 , which is generally consistent with the result of the present study (0.10 in the control group). As far as we know, this is the first study to link this gene variant with NTD risk, which demonstrated lower odds of NTDs in G allele carriers. The protective role of $\mathrm{G}$ alleles might be due to intact MnSOD activity, which is otherwise impaired in the AA genotype. In the present study, $\mathrm{G}$ allele carriers with high $\mathrm{Cd}$ exposure was associated with much higher NTD risk when compared to fetuses who did not carry $\mathrm{G}$ alleles, suggesting the modification effect of this SNP on the NTD risk in association with $\mathrm{Cd}$ exposure. This result was consistent with another study, in which peripheral blood mononuclear cells (PBMCs) derived from people with GG genotype showed higher sensitivity to pyridostigmine bromide (PB)-induced oxidative stress [43]. On the other

Table 4 Association between single-nucleotide polymorphisms (SNPs) in fetal SOD2 and MTHFR and risk for neural tube defects

\begin{tabular}{|c|c|c|c|c|}
\hline SNP and genotype & Controls [n (\%)] & Cases [n (\%)] & OR $(95 \% \mathrm{Cl})$ & $P$ \\
\hline \multicolumn{5}{|l|}{ SOD2 rs4880 } \\
\hline AA & $104(72.2)$ & $125(80.6)$ & 1 & \\
\hline$A G$ & $35(24.3)$ & $29(18.7)$ & $0.69(0.40-1.20)$ & 0.190 \\
\hline GG & $5(3.5)$ & $1(0.6)$ & $0.17(0.02-1.45)$ & 0.104 \\
\hline$P$ for trend & & & & 0.045 \\
\hline \multicolumn{5}{|l|}{ MTHFR rs1801133 } \\
\hline $\mathrm{CC}$ & $24(16.7)$ & 18 (11.6) & 1 & \\
\hline CT & $78(54.5)$ & $78(50.3)$ & $1.33(0.67-2.65)$ & 0.412 \\
\hline $\mathrm{TT}$ & $41(28.7)$ & $59(38.1)$ & $1.92(0.93-3.98)$ & 0.080 \\
\hline$P$ for trend & & & & 0.059 \\
\hline
\end{tabular}


Table 5 Interaction between single-nucleotide polymorphisms (SNPs) in fetal SOD2 and MTHFR and cadmium (Cd) exposure on NTD risk

\begin{tabular}{|c|c|c|c|c|c|c|c|}
\hline SNP and genotype & Cd level & Cases & Controls & cOR $(95 \% \mathrm{Cl})$ & $P$ & aOR $(95 \% \mathrm{Cl})$ & $P^{a}$ \\
\hline \multicolumn{8}{|l|}{ SOD2 rs4880 } \\
\hline \multirow[t]{2}{*}{$\mathrm{AA}$} & Low & 61 & 54 & 1 & & 1 & \\
\hline & High & 64 & 50 & $1.13(0.67-1.91)$ & 0.638 & $1.08(0.63-1.87)$ & 0.776 \\
\hline \multirow[t]{2}{*}{ GG\&AG } & Low & 7 & 25 & 1 & & 1 & \\
\hline & High & 23 & 15 & $5.48(1.90-15.82)$ & 0.002 & $3.77(1.15-12.36)$ & 0.028 \\
\hline Multiplicative interaction ${ }^{b}$ & & & & $4.83(1.48-15.76)$ & 0.009 & $4.43(1.30-15.07)$ & 0.017 \\
\hline Additive interaction $^{c}$ & & & & $0.77(0.46-1.09)$ & $<0.0001$ & $0.76(0.42-1.11)$ & $<0.0001$ \\
\hline \multicolumn{8}{|l|}{ MTHFR rs1801133 } \\
\hline \multirow[t]{2}{*}{$\mathrm{CC}$} & Low & 11 & 11 & 1 & & & \\
\hline & High & 7 & 13 & $0.54(0.16-1.87)$ & 0.329 & $0.87(0.23-3.32)$ & 0.834 \\
\hline \multirow[t]{2}{*}{ CT\&TT } & Low & 57 & 68 & 1 & & & \\
\hline & High & 80 & 51 & $1.87(1.14-3.08)$ & 0.014 & $1.55(0.91-2.64)$ & 0.106 \\
\hline Multiplicative interaction ${ }^{b}$ & & & & $3.48(0.91-13.25)$ & 0.068 & $2.68(0.67-10.74)$ & 0.164 \\
\hline Additive interaction ${ }^{c}$ & & & & $0.74(0.27-1.20)$ & 0.0019 & $0.64(0.02-1.25)$ & 0.042 \\
\hline
\end{tabular}

Abbreviations: cOR crude odds ratio, aOR adjusted odds ratio

${ }^{\text {a }}$ Adjusted for folic acid supplementation

${ }^{\mathrm{b}}$ Multiplicative interaction was measured by a cross-product term by genotype and metal level

c Additive interaction was measured by the relative excess risk of interaction (RERI)

hand, another SNP of SOD2 investigated in this study, rs5746105, showed Hardy-Weinberg disequilibrium. This deviation might be due to the limited sample size. The power of the HWE test of this SNP was 0.22, as calculated by PASS version 11 .

MTHFR (5,10-methylenetetrahydrofolatereductase) encodes a crucial enzyme in folate metabolism, which catalyzes the conversion of 5,10-methylenetetrahydrofolate to 5-methyltetrahydrofolate. C677T (rs1801133) is a common polymorphism in MTHFR. This variant hampers the enzyme activity [44] and is consistently linked with elevated plasma total homocysteine levels [45], which has been related to the genesis of NTDs [46, 47]. The prevalence of $T$ alleles is diverse among ethnicities, being approximately 0.29 in the East Asian population according to the gnomAD database. However, the frequency of the $\mathrm{T}$ allele in the present study is approximately 0.59 (case group, 0.63; control group, 0.56 ), which is much higher than this value. A large-scale epidemiological study with over 20,000 Chinese participants revealed a $\mathrm{T}$ allele frequency of 0.49 [48]. These results indicated that the Chinese population might possess a higher frequency of $\mathrm{T}$ alleles than other populations in Eastern Asia, which might be attributable to a higher NTD risk in China [49]. Either in the mother or the child, T alleles confer a modestly increased NTD risk in the allelic (additive) model $[47,50]$, but the results were not always consistent among populations [51]. We found that the $\mathrm{T}$ allele enhances the risk effect of $\mathrm{Cd}$ exposure on NTD risk, suggesting that $\mathrm{T}$ allele carriers are more vulnerable to adverse environmental factors, even though the genotypic factor alone did not confer a significant increase in NTD risk. The possible mechanism underlying this interaction may also be related to oxidative stress. Numerous studies have shown that folate has antioxidative properties, and homocysteine can induce oxidative stress [52,53]. Subjects carrying the TT genotype in MTHFR rs1801133 have lower folate levels and higher homocysteine levels $[44,47]$, which may exacerbate the effect of oxidative stress induced by $\mathrm{Cd}$ exposure.

The majority of the women included in this study lived in rural areas and reported farming as their occupation. No occupational exposure or facility-associated sources of metals were identified. However, the province from which the study subjects were recruited has rich coal reserves and production [54]. Coal is the main source of energy for domestic heating and cooking, and coal-consuming industries were prevalent in the province. A previous study suggested that coal combustion was responsible for the deposition of heavy metals in the air in the Shanxi basin [55]. Contents of $\mathrm{Cd}$ and $\mathrm{Pb}$ in coal produced in Shanxi Province are higher than those from the United States [56]. These findings suggest that residents in Shanxi Province may live with an aggravated environmental burden of $\mathrm{Cd}$ and $\mathrm{Pb}$, which might be partly responsible for the higher NTD risk in the population.

Several strengths and limitations of this study should be addressed. First, the umbilical cord tissue has been scarcely investigated as an environmental exposure indicator for fetuses. As a tissue that shares a common origin 
with the fetus body and develops in the same environment, umbilical cord tissue should be a better biospecimen for assessing fetal exposure than placenta tissue, maternal blood, or maternal scalp hair. Metal concentrations in cord tissue may represent long-term exposure of the fetus. Second, we combined genetic and environmental factors (i.e., $\mathrm{Cd}$ or $\mathrm{Pb}$ exposure levels) to analyze their interrelationships on NTD risk, which provided a more comprehensive picture to understand the etiology of NTDs. However, due to the limited number of subjects, the power to detect the association between metals or genetic variants and NTD risks is limited. Second, although the selection of the SNPs in this study was based on a candidate gene approach, examination of the associations for 20 SNPs may result in false-positive results in a study with a limited sample size like the present one. Thus, the conclusion drawn from this study needs to be replicated in the future with larger sample sizes. Another limitation lies in the timing during which we collected the umbilical cord tissues, which did not parallel the time frame of neural tube closure due to the intrinsic nature of the outcomes examined. Thus, the metal concentration we obtained in this study might not exactly reflect the exposure levels during neural tube closure.

\section{Conclusion}

Higher concentrations of $\mathrm{Cd}$, but not $\mathrm{Pb}$, in umbilical cord tissue were associated with a higher risk for NTDs. G alleles in SOD2 rs4880 tended to be associated with a reduced risk, but $\mathrm{T}$ alleles in MTHFR rs1801133 to be associated with an increased risk for NTDs. Moreover, G alleles of rs4880 and $\mathrm{T}$ alleles of rs1801133 might enhance the association between higher $\mathrm{Cd}$ level and increased NTD risk, as compared to their wild-type genotypes. This study provided novel evidence on gene-environment interactions in the etiology of NTDs, but the findings need to be substantiated in large-scale studies in the future.

\section{Abbreviations \\ Cd: Cadmium; Pb: Lead; Mn: Manganese; NTDs: Neural tube defects; SNPs: Single nucleotide polymorphisms; OR: Odds ratio; RERI: Relative excess risk of interaction; MTHFR: 5,10-Methylenetetrahydrofolatereductase; SOD: Superox- ide dismutase; HWE: Hardy-Weinberg Equilibrium.}

\section{Supplementary Information}

The online version contains supplementary material available at https://doi. org/10.1186/s12940-021-00752-9.

Additional file 1: Supplementary Table S1. Information of 20 single nucleotide polymorphisms (SNPs) of 9 genes examined in this study. Supplementary Table S2. Median (P25-P75) concentration of elements with and without folic acid supplementation. Supplementary Table S3. Association between SNP and odds of NTDs with no statistical significance.

\section{Acknowledgements}

Not applicable

\section{Conflict of interest}

The authors declare they have no actual or potential competing financial interests.

\section{Authors' contributions}

M. L. analyzed the data and drafted the manuscript. L. J. designed the research. J. Y., Z. S., Y. S., Y. L., Q. X., Z. L., and L. W. conducted the research. A. R. supervised the research, revised the manuscript, and had primary responsibility for the final content. All authors read and approved the final manuscript.

\section{Funding}

This work was supported by the National Key Research and Development Program, Ministry of Science and Technology of the People's Republic of China (Grant No. 2016YFC1000501). The funding agency has no role in study design, implementation, data analysis, and interpretation.

\section{Availability of data and materials}

The datasets generated and/or analyzed during the current study are not publicly available due to ethical and legal reasons but are available from the corresponding author on reasonable request.

\section{Declarations}

\section{Ethics approval and consent to participate}

This study was approved by the biomedical ethics committee of Peking University (Beijing, China), and all mothers provided consent before participation.

\section{Consent for publication \\ Not applicable.}

\section{Competing interests}

The authors declare that they have no competing interests.

\section{Author details}

${ }^{1}$ Institute of Reproductive and Child Health/Key Laboratory of Reproductive Health, National Health Commission of the People's Republic of China, Peking University, Beijing, China. ${ }^{2}$ Department of Epidemiology and Biostatistics, School of Public Health, Peking University, Beijing, China. ${ }^{3}$ Beijing Obstetrics and Gynecology Hospital, Capital Medical University, Beijing, China.

Received: 24 July 2020 Accepted: 24 May 2021

Published online: 05 June 2021

\section{References}

1. Williams J, Mai CT, Mulinare J, Isenburg J, Flood TJ, Ethen M, Frohnert B, Kirby RS, C. Centers for Disease, and Prevention. Updated estimates of neural tube defects prevented by mandatory folic acid fortification United States, 1995-2011. MMWR Morb Mortal Wkly Rep. 2015;64(1):1-5.

2. Li Z, Ren A, Zhang L, Ye R, Li S, Zheng J, Hong S, Wang T, Li Z. Extremely high prevalence of neural tube defects in a 4-county area in Shanxi Province, China. Birth Defects Res A Clin Mol Teratol. 2006;76(4):237-40.

3. Copp AJ, Stanier P, Greene ND. Neural tube defects: recent advances, unsolved questions, and controversies. Lancet Neurol. 2013;12(8):799-810.

4. Daly LE, Kirke PN, Molloy A, Weir DG, Scott JM. Folate levels and neural tube defects. Implications for prevention. JAMA. 1995;274(21):1698-702.

5. Blom HJ, Shaw GM, den Heijer M, Finnell RH. Neural tube defects and folate: case far from closed. Nat Rev Neurosci. 2006;7(9):724-31.

6. Prevention of neural tube defects: results of the Medical Research Council Vitamin Study MRC Vitamin Study Research Group. Lancet 1991:338(8760):131-7.

7. Czeizel $A E$, Dudas I. Prevention of the first occurrence of neural-tube defects by periconceptional vitamin supplementation. N Engl J Med. 1992;327(26):1832-5 
8. Berry RJ, Li Z, Erickson JD, Li S, Moore CA, Wang H, Mulinare J, Zhao P, Wong LY, Gindler J, et al. Prevention of neural-tube defects with folic acid in China. China-U.S. Collaborative Project for Neural Tube Defect Prevention. N Engl J Med. 1999;341 (20):1485-90.

9. Agopian AJ, Tinker SC, Lupo PJ, Canfield MA, Mitchell LE, S. National Birth Defects Prevention. Proportion of neural tube defects attributable to known risk factors. Birth Defects Res A Clin Mol Teratol. 2013;97(1):42-6.

10. Webster WS, Messerle K. Changes in the mouse neuroepithelium associated with cadmium-induced neural tube defects. Teratology. 1980;21(1):79-88.

11. Papaconstantinou AD, Brown KM, Noren BT, McAlister T, Fisher BR, Goering PL. Mercury, cadmium, and arsenite enhance heat shock protein synthesis in chick embryos prior to embryotoxicity. Birth Defects Res B Dev Reprod Toxicol. 2003;68(6):456-64.

12. Thompson J, Hipwell E, Loo HV, Bannigan J. Effects of cadmium on cell death and cell proliferation in chick embryos. Reprod Toxicol. 2005:20(4):539-48.

13. Chow ES, Hui MN, Lin CC, Cheng SH. Cadmium inhibits neurogenesis in zebrafish embryonic brain development. Aquat Toxicol. 2008;87(3):157-69.

14. Bound JP, Harvey PW, Francis BJ, Awwad F, Gatrell AC. Involvement of deprivation and environmental lead in neural tube defects: a matched case-control study. Arch Dis Child. 1997:76(2):107-12.

15. Cengiz B, Soylemez F, Ozturk E, Cavdar AO. Serum zinc, selenium, copper, and lead levels in women with second-trimester induced abortion resulting from neural tube defects: a preliminary study. Biol Trace Elem Res. 2004;97(3):225-35.

16. Demir N, Basaranoglu M, Huyut Z, Deger I, Karaman K, Sekeroglu MR, Tuncer $O$. The relationship between mother and infant plasma trace element and heavy metal levels and the risk of neural tube defect in infants. J Matern Fetal Neonatal Med. 2019;32(9):1433-40.

17. Dawson EB, Evans DR, Harris WA, Van Hook JW. Amniotic fluid B12, calcium, and lead levels associated with neural tube defects. Am J Perinatol. 1999;16(7):373-8.

18. Luo Y, McCullough LE, Tzeng JY, Darrah T, Vengosh A, Maguire RL, Maity A, Samuel-Hodge C, Murphy SK, Mendez MA, et al. Maternal blood cadmium, lead and arsenic levels, nutrient combinations, and offspring birthweight. BMC Public Health. 2017;17(1):354.

19. Sun $H$, Chen W, Wang $D$, Jin $Y$, Chen $X, X u$ Y. The effects of prenatal exposure to low-level cadmium, lead and selenium on birth outcomes. Chemosphere. 2014:108:33-9.

20. Vidal AC, Semenova V, Darrah T, Vengosh A, Huang Z, King K, Nye MD, Fry R, Skaar D, Maguire R, et al. Maternal cadmium, iron and zinc levels, DNA methylation and birth weight. BMC Pharmacol Toxicol. 2015;16:20.

21. Hsu PC, Guo YL. Antioxidant nutrients and lead toxicity. Toxicology. 2002;180(1):33-44.

22. Zhang RK, Wang P, Lu YC, Lang L, Wang L, Lee SC. Cadmium induces cell centrosome amplification via reactive oxygen species as well as endoplasmic reticulum stress pathway. J Cell Physiol. 2019:234(10):18230-48

23. Tanekhy M. Lead poisoning in Nile tilapia (Oreochromis niloticus): oxidant and antioxidant relationship. Environ Monit Assess. 2015;187(4):154

24. Cardoso BR, Roberts BR, Bush Al, Hare DJ. Selenium, selenoproteins and neurodegenerative diseases. Metallomics. 2015;7(8):1213-28.

25. Fridovich I. Superoxide anion radical (O2-.), superoxide dismutases, and related matters. J Biol Chem. 1997;272(30):18515-7.

26. Ren A, Qiu X, Jin L, Ma J, Li Z, Zhang L, Zhu H, Finnell RH, Zhu T. Association of selected persistent organic pollutants in the placenta with the risk of neural tube defects. Proc Natl Acad Sci U S A. 2011;108(31):12770-5.

27. Liu J, Zhang L, Li Z, Jin L, Zhang Y, Ye R, Liu J, Ren A. Prevalence and trend of neural tube defects in five counties in Shanxi province of Northern China, 2000 to 2014. Birth Defects Res A Clin Mol Teratol. 2016;106(4):267-74.

28. Ni W, Yang W, Yu J, Li Z, Jin L, Liu J, Zhang Y, Wang L, Ren A. Umbilical cord concentrations of selected heavy metals and risk for orofacial clefts. Environ Sci Technol. 2018;52(18):10787-95.

29. Demidenko E. Nonlinear mixed effects model. Mixed models. 2013: p. 433-486.
30. Sakamoto M, Yasutake A, Domingo JL, Chan HM, Kubota M, Murata K. Relationships between trace element concentrations in chorionic tissue of placenta and umbilical cord tissue: potential use as indicators for prenatal exposure. Environ Int. 2013;60:106-11.

31. Liang CM, Wu XY, Huang K, Yan SQ, Li ZJ, Xia X, Pan WJ, Sheng J, Tao YR, Xiang $\mathrm{HY}$, et al. Trace element profiles in pregnant women's sera and umbilical cord sera and influencing factors: repeated measurements. Chemosphere. 2019;218:869-78.

32. Guy M, Accrombessi M, Fievet N, Yovo E, Massougbodji A, Le Bot B, Glorennec $\mathrm{P}$, Bodeau-Livinec $\mathrm{F}$, Briand $\mathrm{V}$. Toxics (Pb, $\mathrm{Cd}$ ) and trace elements $(\mathrm{Zn}, \mathrm{Cu}, \mathrm{Mn})$ in women during pregnancy and at delivery, South Benin, 2014-2015. Environ Res. 2018;167:198-206.

33. Edwards MJ. Review: hyperthermia and fever during pregnancy. Birth Defects Res A Clin Mol Teratol. 2006;76(7):507-16.

34. Chambers $C D$. Risks of hyperthermia associated with hot tub or spa use by pregnant women. Birth Defects Res A Clin Mol Teratol. 2006;76(8):569-73.

35. Milunsky A, Ulcickas M, Rothman KJ, Willett W, Jick SS, Jick H. Maternal heat exposure and neural tube defects. JAMA. 1992;268(7):882-5.

36. Hornig M, Bresnahan MA, Che X, Schultz AF, Ukaigwe JE, Eddy ML, Hirtz D, Gunnes N, Lie KK, Magnus P, et al. Prenatal fever and autism risk. Mol Psychiatry. 2018;23(3):759-66.

37. Dombrowski SC, Martin RP, Huttunen MO. Association between maternal fever and psychological/behavior outcomes: a hypothesis. Birth Defects Res A Clin Mol Teratol. 2003:67(11):905-10.

38. Edwards MJ, Saunders RD, Shiota K. Effects of heat on embryos and foetuses. Int J Hyperthermia. 2003;19(3):295-324.

39. Rosenblum JS, Gilula NB, Lerner RA. On signal sequence polymorphisms and diseases of distribution. Proc Natl Acad Sci U S A. 1996;93(9):4471-3.

40. Sutton A, Khoury H, Prip-Buus C, Cepanec C, Pessayre D, Degoul F. The Ala16Val genetic dimorphism modulates the import of human manganese superoxide dismutase into rat liver mitochondria. Pharmacogenetics. 2003;13(3):145-57.

41. Nahon P, Charnaux N, Friand V, Prost-Squarcioni C, Ziol M, Lievre N, Trinchet JC, Beaugrand M, Gattegno L, Pessayre D, et al. The manganese superoxide dismutase Ala16Val dimorphism modulates iron accumulation in human hepatoma cells. Free Radic Biol Med. 2008;45(9):1308-17.

42. Bresciani G, Cruz IB, de Paz JA, Cuevas MJ, Gonzalez-Gallego J. The MnSOD Ala16Val SNP: relevance to human diseases and interaction with environmental factors. Free Radic Res. 2013:47(10):781-92.

43. Azzolin VF, Barbisan F, Teixeira CF, Pillar D, Mastella MH, Duarte T, Turra BO, Ribeiro EE, Duarte M, da Cruz IBM. The Val16Ala-SOD2 polymorphism affects cyto-genotoxicity of pyridostigmine bromide on human peripheral blood mononuclear cells. Toxicol In Vitro. 2019:60:237-44.

44. Frosst P, Blom HJ, Milos R, Goyette P, Sheppard CA, Matthews RG, Boers GJ den Heijer M, Kluijtmans $L A$, van den Heuvel $L P$, et al. A candidate genetic risk factor for vascular disease: a common mutation in methylenetetrahydrofolate reductase. Nat Genet. 1995;10(1):111-3.

45. Brattstrom L, Wilcken DE, Ohrvik J, Brudin L. Common methylenetetrahydrofolate reductase gene mutation leads to hyperhomocysteinemia but not to vascular disease: the result of a meta-analysis. Circulation. 1998;98(23):2520-6.

46. Finnell RH, Greer KA, Barber RC, Piedrahita JA. Neural tube and craniofacial defects with special emphasis on folate pathway genes. Crit Rev Oral Biol Med. 1998;9(1):38-53.

47. van der Put NM, Steegers-Theunissen RP, Frosst P, Trijbels FJ, Eskes TK, van den Heuvel LP, Mariman EC, den Heyer M, Rozen R, Blom HJ. Mutated methylenetetrahydrofolate reductase as a risk factor for spina bifida. Lancet. 1995;346(8982):1070-1.

48. Huo Y, Li J, Qin X, Huang Y, Wang X, Gottesman RF, Tang G, Wang B, Chen $D, H e M$, et al. Efficacy of folic acid therapy in primary prevention of stroke among adults with hypertension in China: the CSPPT randomized clinical trial. JAMA. 2015;313(13):1325-35.

49. Yang B, Fan S, Zhi X, Xia R, Wang Y, Zheng Q, Sun G. Geographical and ethnic distribution of MTHFR gene polymorphisms and their associations with diseases among Chinese population. Clin Genet. 2017;92(3):243-58. 
50. Botto LD, Yang Q. 5,10-Methylenetetrahydrofolate reductase gene variants and congenital anomalies: a HuGE review. Am J Epidemiol. 2000;151(9):862-77.

51. Papapetrou C, Lynch SA, Burn J, Edwards YH. Methylenetetrahydrofolate reductase and neural tube defects. Lancet. 1996;348(9019):58.

52. Loscalzo J. The oxidant stress of hyperhomocyst(e)inemia. J Clin Invest. 1996;98(1):5-7.

53. Welch GN, Loscalzo J. Homocysteine and atherothrombosis. N Engl J Med. 1998;338(15):1042-50.

54. Kehrer JP. The Haber-Weiss reaction and mechanisms of toxicity. Toxicology. 2000;149(1):43-50.

55. Zhong C, Yang Z, Jiang W, Yu T, Hou Q, Li D, Wang J. Annual input fluxes and source identification of trace elements in atmospheric deposition in Shanxi Basin: the largest coal base in China. Environ Sci Pollut Res Int 2014;21(21):12305-15.

56. Zhang JY, Zheng CG, Ren DY, Chou CL, Liu J, Zeng RS, et al. Distribution of potentially hazardous trace elements in coals from Shanxi province, China. Fuel. 2004:83:129-35.

\section{Publisher's Note}

Springer Nature remains neutral with regard to jurisdictional claims in published maps and institutional affiliations.
Ready to submit your research? Choose BMC and benefit from:

- fast, convenient online submission

- thorough peer review by experienced researchers in your field

- rapid publication on acceptance

- support for research data, including large and complex data types

- gold Open Access which fosters wider collaboration and increased citations

- maximum visibility for your research: over $100 \mathrm{M}$ website views per year

At BMC, research is always in progress.

Learn more biomedcentral.com/submissions 